
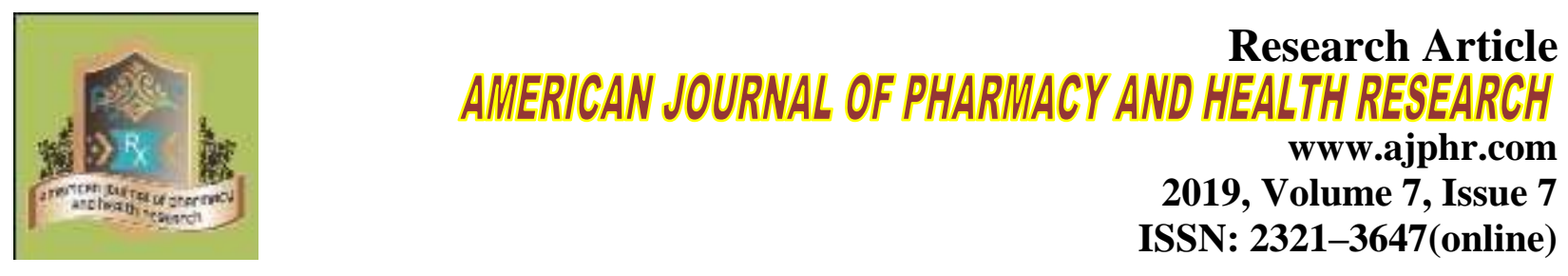

\title{
Comparative Study of Different Varieties of Polished and Unpolished Rice of Ghoti Region
}

\author{
Darshana Varma*, Y. V. Ushir, Prasad Kharche \\ S.M.B.T. Institute of D. Pharmacy, Dhamangaon, Dist. Nashik, India
}

\begin{abstract}
Rice (Oryza sativa Linn.) is one of the most widely consumer food for large part of human population. In India agricultural commodity with $3^{\text {rd }}$ highest worldwide population. The present work is to comparative between polished and unpolished rice of different varieties of rice of Ghoti region and varieties of rice selected are Kolpi and Indrayani rice for my work. The comparative between the rice can identify by Estimation of Total carbohydrate, Estimation of Total protein and Estimation of Total starch. With the main object is to know phytochemical between varieties of polished and unpolished rice, to identify nutritious in varieties of rice, To spread scientific awareness of polished and unpolished rice and to identify adulterant.
\end{abstract}

Keywords: Total carbohydrate, Total starch and Total protein 


\section{INTRODUCTION}

Rice is most widely consumed staple food for large part of world human populations in Asia. There are valt is agricultural commodity with 3rd highest populations [1][2]. There are varieties of rice in India, Ghoti region is famous for rice cultivation. In Ghoti region three varieties of rice is famous and they are Kolpi, Indrayani, and 1008. The kolpi rice is native to Tamil nadu, Indrayani is native to Mulshi Pune and 1008 is native to Ghoti. From above three varieties we had selected two that is Indrayani and kolpi for my work.

Unpolished rice contain large amount of fiber. As rice is whole grain, it contains three components that are bran, germ, and endosperm. Endosperm is left intact, it generates all of protein, and the Bran contains approximately $80 \%$ of minerals. The Germ contain vit-E, minerals, unsaturated fats, antioxidant and phytochemical which are chemically found in fruits, vegetables, beams, and other type of plant food. Antioxidant level is highest in unpolished rice. Unpolished rice consists of nutrient like thiamin, also vit-B1 as well as other vitamin [3],[4].

Polished rice refers to rice which has beem milled to remove the husk, bran, germ, and varying in them, leaving a starch-rich grain. In contrast, rice from which the husk has been removed but with the bran partly or fully left intact is also consumed in many pockets, and this is referred to as unpolished rice or brown rice polished rice has less moisture, mineral, biotin, niacin, protein and fatty content than brown or lightly milled rice. Awhite rice is often enriched with some of the nutrient stripped from it during its processing. A diet based on un enriched white rice leaves many people vulnerable to the neurological disease beri- beri, due to deficiency of thiamine (VitB1) [5][6][7].

The qualified brown rice as an excellent source of manganese and a good source of selenium ,phosphorous , copper, magnesium and niacin (vitamin B3).The complete milling and polishing the convert brown rice into white rice destroys $67 \%$ of vitamin $\mathrm{B} 3,80 \%$ of vitamin $\mathrm{B} 1,90 \%$ of vitamin B6, half of manganese, half of the phosphorous, $60 \%$ of iron and all of the dietary fiber and essential fatty acid. By law in united state, fully milled polished rice must be "enriched" with vitamin B1, B3 and iron. The form of nutrient when added back into processed rice is not same as in original unprocessed version and at least 11 lost nutrient are replaced in any form even with rice "enrichment". A study published in the American Journal of clinical nutrition under scroses the importance of choosing whole grain rather than refined grain i.e. polished rice[8][9][10].

Fibers present in rice are effective against breast cancer. The researcher looked at how much fiber 35,972 participant in UK women's cohort study are they found in rich in fibers from whole 
grain such as brown rice they offer significant protection against breast cancer for premenopausal women (code JE, Burley UJ, et, al, International Journal of Epidemiology).Fibers spilled by brown rice or whole grain offered the most protection . The pre-menopausal women eating the most whole grain fiber (At least $13 \mathrm{gm} /$ day)had a $41 \%$ reduced risk of breast cancer, compared to those with the lowest whole grain fiber intake (4gm or less per day) [11][12]

\section{MATERIALS AND METHOD}

\section{Sample Collection}

The rice sample are collected from Ghoti . As Ghoti region is famous for cultivation of rice from which three varieties of rice is famous that are Indrayani, kolpi, and 1008 rice. From above three varieties two varieties of is selected that is kolpi and Indrayani rice

\section{Protein content}

Pipette out the reagent into suitable container. Mix thoroughly by vortexing and incubate for 30 minute at $25^{\circ} \mathrm{C}$ Transfer to suitable cuvettes and record the absorbance at 550nmPrepare a standard calibration curve for standard protein Determine the mg of protein present in the sample[Table 1]

Table 1: Estimation of Starch in Varieties of Polished and Unpolished Rice of Ghoti Region

\begin{tabular}{lll}
\hline $\begin{array}{l}\text { Sr } \\
\text { no }\end{array}$ & Variety of rice & $\begin{array}{l}\text { Total Starch } \\
(\mathbf{\%} \text { w } / \mathbf{w})\end{array}$ \\
\hline 1 & Unpolished Kolpi rice & 32 \\
2 & Unpolished Indrayani rice & 28 \\
3 & Polish Kolpi rice & 50 \\
4 & Polish Indrayani rice & 45 \\
\hline
\end{tabular}

\section{Carbohydrate content}

Add $\mathrm{NaCo} 3$ until Effervescence. Pipette out $100 \mathrm{mg}$ of glucose $+5 \mathrm{ml}$ of $2.5 \mathrm{NHCl}$ and boil for $3 \mathrm{hrs}$. Cool at R.Tt $0.2,0.4,0.6,0.8$ and $1 \mathrm{ml}$ of working standard Sample prepared similarly Set blank with Add $1 \mathrm{ml}$ of phenol solution $+5 \mathrm{ml}$ of $96 \%$ of H2SO4Keep aside for 10 minute in water bath at $25-30^{\circ} \mathrm{C}$ for 20 minute . Measure the color at $490 \mathrm{~nm}$ Equation: $-100 \mathrm{ml}$ of sample solution contain $=\mathrm{X} 10 \% \mathrm{x} 100 \mathrm{mg}$ of glucose $=\%$ of $\quad$ Total Carbohydrate presents [Table 2]

Table 2: Estimation of carbohydrate in Varieties of Polished and Unpolished Rice of Ghoti Region 


\begin{tabular}{lll}
\hline Sr no & varieties of rice & $\begin{array}{l}\text { Carbohydrate } \\
(\mathbf{w} / \mathbf{w} \%)\end{array}$ \\
\hline 1 & Unpolished Indrayani rice & 29.56 \\
2 & Unpolished Kolpi rice & 19.25 \\
3 & P0lish Indrayani rice & 26.26 \\
4 & Polish Kolpi rice & 12.5 \\
\hline
\end{tabular}

\section{Starch content}

Small pieces of rice and record the initial weight .Grind them with water .Collect the rice homogenate into beaker. Filter the homogenate through a muslin cloth. Allow the filter to settle starch rapidly settle at the bottom. Decant the starch free supernatant. Wash 3-4 times and decant the supernatant. Collect the compact moss of starch and allow it to dry

The given sample contains - gm of starch/100gm of rice [Tabel3]

Table 3: Estimation of protein in Varieties of Polished and Unpolished Rice of Ghoti Region

\begin{tabular}{lll}
\hline Sr no & Variety of rice & Protein \\
\hline 1 & Unpolished Kolpi rice & 0.9225 \\
2 & Unpolished Indrayani rice & 0.32125 \\
3 & Polish Kolpi rice & 0.305 \\
4 & Polish Indrayani rice & 0.135 \\
\hline
\end{tabular}

\section{RESULTS AND CONCLUSION}

As per above result unpolished kolpi (0.9225) rice consist of large amount of protein as compare unpolished Indrayani rice(0.32125). Polished Kolpi rice consist of large amount of starch as (32) compare to polished Indrayani rice(28). Unpolished Indrayani rice consist of large amount of carbohydrate as (29.56) compare to unpolished Kolpi rice(19.25). Unpolished rice consist of large amount of carbohydrate as compare to polished rice. Polished rice consist of large amount of starch as compare to unpolished rice .

\section{REFERENCE}

1. Food and Agriculture Organization, Corporate Statistical Database (FAOSTAT). 2017. Retrieved November 9, 2018.

2. Smith, Bruce D. (1998) the Emergence of Agriculture. Scientific American Library, a Division of HPHLP, New York.

3. Smith, Bruce D. (1998) the Emergence of Agriculture. Scientific American Library, A Division of HPHLP, New York.

4. Carpenter KJ (2000). Beriberi, white rice, and vitamin B: a disease, a cause, and a cure. Berkeley, CA: University of California Press. 
5. "Christian Eijkman, Beriberi and Vitamin B1". Nobelprize.org. Retrieved 28 September 2015.

6. Perkins S. "How Is White Rice Healthy for Our Body". LIVESTRONG.COM. Retrieved 28 September 2015.

7. "U.S. Code $\S 1431 \mathrm{c}$ - Enrichment and packaging of cornmeal, grits, rice, and white flour available for distribution". Cornell.edu. Retrieved 28 September 2015.

8. Anderson JW, Hanna TJ, Peng X, Kryscio RJ. Whole grain foods and heart disease risk. J Am Coll Nutr 2000 Jun;19.Worlds healthiest food George Matalan Foundation. November 19-2-2018

9. Cade J.E, Burley VJ, Greenwood DC. Dietary fiber and risk of breast cancer in the UK Women's Cohort Study. Int J Epidemiol. 2007 Jan 24. 2007. The Worlds healthiest food George Matalan Foundation. November 19-2-2018

10. Ensminger AH, Ensminger, ME, Kondale JE, Robson JRK. Foods \& Nutrition Encyclopedia. Pegus Press, Clovis, California. 1983. The Worlds healthiest food George Matalan Foundation. November 19-2-2018

11. Liu RH. New finding may be key to ending confusion over link between fibers, colon cancer. American Institute for Cancer Research Press Release, November 3, 2004. The Worlds healthiest food George Matalan Foundation. November 19-2-2018

12. Liu S, Willett WC, Manson JE, Hu FB, Rosner B, Colditz G. Relation between changes in intakes of dietary fiber and grain products and changes in weight and development of obesity among middle-aged women. Am J Clin Nutr. 2003 November. The Worlds healthiest food George Matalan Foundation. November 19-2-2018

13. Dr.S.S Khadabadi, Dr .S.S Deore, B.A Baviskar . 'Experimental phytopharmacy, Niral Prakasan'. Second edition: - Feb 2013 pg No 4.4

14. Dr .S.S Khadabadi . Dr .S.L Deore, B.A Baviskar. 'Experimental phytopharmacy, Niral Prakasan'. Second edition: - Feb 2013 pg No 4.1

15. Dr. Mahesha H.B, Yuvaraja's College, Mysore . Extraction of starch from potatoes 